\title{
FMEA Study Proposal with Application in a White-Good Appliances Product
}

\author{
Sheyla Cardoso Andrade, William Nicolas de Oliveira Coelho, Marcelo Albuquerque de Oliveira, \\ Gabriela de Mattos Veroneze, Dercio Luiz Reis, and Joaquim Maciel da Costa Craveiro
}

\section{ABSTRACT}

One of the growing concerns in companies in developed countries and in Brazil is to look for new ways to stay in the market, increasing their productivity and improving the quality of their products. The FMEA methodology allows us to avoid, through the analysis of potential failures and proposals for improvement actions, failures in the design of the product or process occur, in order to increase reliability. The reliability of a product is the reflection of the number of failures it presents when subjected to stress tests, thus helping in the detection of problems, determining the time to be offered as a guarantee and helping in the prevention of new failures. The objective of this article is to present a proposal for the application of an FMEA in a white line company, where there is a product with a high failure rate, in which this issue will be analyzed and direct proposals for improvements, seeking to reduce its occurrence in the product.

Keywords: Continuous Improvement, Failure, FMEA, Reliability.
Submitted : September 11, 2021

Published : November 30, 2021

ISSN: 2507-1076

DOI: $10.24018 /$ ejbmr.2021.6.6.1106

Sheyla Cardoso Andrade*

Graduation student in Production Engineering, Federal University of Amazonas.

(e-mail: sheyla_@outlook.com)

William Nicolas de Oliveira Coelho

Graduation student in Production Engineering, Federal University of Amazonas.

(e-mail: williamnicolas73@gmail.com)

Marcelo de Albuquerque de Oliveira

Professor, PhD, Master's Program in Production Engineering, Federal University of Amazonas.

(e-mail: marcelooliveira@ufam.edu.br)

Gabriela de Mattos Veroneze

Professor, PhD, Master's Program in

Production Engineering, Federal University of Amazonas.

(e-mail: gveroneze@ufam.edu.br)

Dercio Luiz Reis

Professor, PhD, Master's Program in

Production Engineering, Federal University of Amazonas.

(e-mail: dercioreis@ ${ }^{@}$ fam.edu.br)

Joaquim Maciel da Costa Craveiro

Professor, PhD, Master's Program in

Production Engineering, Federal University of Amazonas.

(e-mail: jmaciel@ ufam.edu.br)

*Corresponding Author

\section{INTRODUCTION}

By acquiring a certain product, it is essential that it meets the expectations of its functionality and requests that were externalized by coming up with the buy interest. Although, it can cause damage through the useful life of it. Thinking of it, it is necessary that there is a parameter, which should be connected to the product's state related to time. To product verification and monitoring is very important that it is understood how it behaves through the years, by a constant daily use of its user. Having it in mind, it's inserted the processes' production reliability, such as the quality projection through time. Most of the products start their lives with low rates, and after they must present an increase at the end of the year's continuous use.

The Failure Mode Effects Analysis (FMEA) methodology is a tool that searches by the potential failure analysis and proposes actions to enhance, on projects or processes. The failure processes are inevitable, although searching for methods and tools to reduce the failure numbers or even reach to zero, in specific periods, it is essential. A long time ago, it abandoned the concept that it is necessary to wait for the equipment to arrive to a huge number of failures so that it can create an action plan. However, once creating an action plan and classifying the failures that affect the most on the product process is something hard, putting failures in a decreasing way on a priority level. Then, it has caused an increase in the search by more efficient ways of doing the plan, in a way that the company is not focused on the potential failures. Aiming to improve the failures analysis, the FMEA has been a technique exclusively created for failure analysis, in 1949, it has been used by the American Army to identify possible failures on military systems.

Within this work, it has the aim to present a proposal of the FMEA application to a product belonging to a white-good application product. The techniques used for data collecting, 
and information on the article are observation types in real life, where the data have been registered as far as they occurred. The data were collected on Final Test, which is done still on the production line to filter recurrent defects on the productive process.

With the study case method utilization, it is going to be done field research to obtain knowledge of an empiric knowledge within the context of the problem. Through qualitative and quantitative research in a field experiment, carried in August of 2020, it has been possible to collect data with the aim to measure behavior patterns and relation between the variables.

\section{LITERATURE REVIEW}

\section{A. FMEA}

Failure can be defined as the end of availability of an item to do its requested function. To Stamatis (1995), failure is the incapacity of any active do what its user wants it to do. The definition of reliability talks about "correct performance of an equipment or system". The lack of correct performance compliance will be defined as failure. There are failures that can occur under some circumstances of the processes, which can be treated with naturally, for example, the burn of a vehicle intern light. On the other hand, in some cases, if the failure occurs, it can be crucial, for instance, airplanes flying, hospitals' electricity and vehicles' braking (Slack et al., 2008).

The analysis of the type Failure Effect, known as FMEA is a systematic technique to recognize and evaluate potential failures and its causes. Identify actions that eliminate or reduce the probability of its occurrence (Toledo and Amaral, 2006). To make FMEA a product it is necessary to understand clearly how the process works, to monitor data cautiously and feed the table correctly.

The steps to feed the table are: Process/Product - step analyzed on FMEA; Function - It's the aim of FMEA application; Failure Mode - How the failure presents itself; Failure Effect - Impacts caused by the failure; Failure Cause - What has brought about the component failure; Severity (S) - Impact on security failure; Occurrence $(\mathrm{O})$ - Probability of failure mode to occur; Detection (D) - Probability of the failure be detected; RPN (Risk Priority Number) - Risk priority.

It must be given a value to each failure mode as shown: Severity (S): where 1 is "minimum" and 10 are "very high". Occurrence (O): where 1 is "remote" and 10 is "very high". Detection (D): starts with 1 and is "very huge" and 10 "very small". After determining the degree of each failure mode. It's necessary to calculate RPN (Risks), according to the formula:

$$
R P N=S X O \times D
$$

Then scale the failure priority. The bigger the RPN, the more critic is that failure. It is on it that must be applied the preventive actions occurrence (Toledo and Amaral, 2006). Fill the second part of the table with the action plan that has some topics, such as:
- Recommended action: indicated by the manager of the team.

- Responsible: author of the action.

- Deadline: limited date to decision making.

- Actions Taken: what has been really done.

Later assign a value to each failure mode: severity, occurrence, and detection. It can be calculated a new RPN, with the aim to compare it to the previous number, and this way figures out if there has been some failure reduction. Applications of FMEA methodology are found in several areas, according to the work of different authors (Batista et al., 2019; Braaksma et al., 2013; Braaksma et al., 2012).

\section{B. Reliability}

According to NPEN:13306 (2007), "Reliability is the ability of a good to accomplish a function requested under conditions during a period of time" (Moubray, 2000). According to Daneshio et al. (2014), "Reliability is the capacity of an item to perform under some specified conditions, during a period of time". The reliability is applied in the beginning of the project, in the intermediate development phase, final development phase, initial production phase, and production after sales. Thus, it can be done through continuous enhancement over all the products made and creation process (Ming et al., 2015; O'Connor, and Moleh, 2016; Un. and Huibin, 2012; Voinov et al., 2016; Zio et al., 2019).

With the absence of "right performance" of the product, it is defined as failure. According to Gulati and Smith (2009), the main application of reliability in Engineering is on failures' prevention. The reliability of a certain item can be defined as its capacity of doing a certain requested function during a certain period, subjected to a certain mean, under the project's condition (Pham, 2014). According to Oliveira (2017), reliability is the feature of an item eventually expressed through probability that it will fill a given function, under established conditions and for a certain period established. According to those definitions, the concept of reliability has four significant elements:

- Probability: the probability is the reliability; this characterizes the differences within equipment of the same nature and enables us to know how good the ability is to function without failures through certain periods of time.

- Given function: Before starting any study, it is necessary to define the performance of a function and to indicate what the function is about This function performance has a level established by the failure type that occurred, the failure's types are: total or partial, catastrophic or parametric, dependent or independent of other failures, suddenly or gradually, and stable, temporary or intermittent.

- Defined conditions: it's cautiously defined by the application type which will be used the equipment, and the reliability type that will be used. Those types are intrinsic (in testing banks, where the conditions are well controlled) and operational (in real conditions of use).

- Time: the products must work during a certain period of time intermittently or only once, and this parameter can be, according to the situation, a mission duration, a cycle 
number or mileage. The products which the utilization also doesn't observe the time intervention (explosives).

\section{Methodology}

The study object is the Failure Effect Mode Analysis methodology. The FMEA analysis is essential because with it is possible to analyse failures that impact more in the productive process of the product, allowing the application of one or more enhancement proposals, to reduce or eliminate impacts occurred on the existent failure, using a weighted study according to the failure's critical degree, besides obtaining a catalogue of information about failures on product and process.

The FMEA model must have a well-defined scope and goals. With the realization of periodic meetings in the company, with all the members involved, similar to a project which must establish the steps evaluating its progress. In this way, the FMEA was applied following the steps of the Fig. 1.

\section{RESULTS AND DISCUSSIONS}

The FMEA form is a document that enables an analysis of the failures historic of a product/item, since the frequent failures or even the future ones, which still can occur.

There are many models of FMEA forms that can be used according to the problem to be observed, and much specific software that can also do the confection of this form. In this work, the process FMEA model 2 has been used, with the aim to analyses an item of the production process of a white-good line product. The FMEA application proposal in a white-good product line is focused on the item "motor" which is an item that compound the final product.

The obtained data have been collected during the period of January to August of 2020, during eight months of observation in the model.

In Table I, it can be verified the failure "Motor noise" and the frequency in which it appears in the process, during the step "Final Test".

TABLE I: FAILURE FREQUENCY “MOTOR NOISE” FINAL TEST STEP

\begin{tabular}{lccc}
\hline \multicolumn{1}{|c}{$\begin{array}{l}\text { Failures of the } \\
\text { Final Test step }\end{array}$} & $\begin{array}{c}\text { Engine } \\
\text { noise }\end{array}$ & $\begin{array}{c}\text { Total step } \\
\text { failures }\end{array}$ & $\begin{array}{c}\text { Failure } \\
\text { frequency (\%) }\end{array}$ \\
\hline $\begin{array}{l}\text { Noisy engine } \\
\text { Compressor } \\
\text { does not start }\end{array}$ & 127 & 185 & $69 \%$ \\
$\begin{array}{l}\text { Engine does not } \\
\text { start }\end{array}$ & 17 & 185 & $9 \%$ \\
$\begin{array}{l}\text { Panel - broken } \\
\text { command }\end{array}$ & 8 & 185 & $5 \%$ \\
$\begin{array}{l}\text { Panel - exposed } \\
\text { wiring }\end{array}$ & 6 & 185 & $4 \%$ \\
$\begin{array}{l}\text { Panel - fan does } \\
\text { not turn on }\end{array}$ & 6 & 185 & $3 \%$ \\
$\begin{array}{l}\text { Panel does not } \\
\text { turn on }\end{array}$ & 5 & 185 & $3 \%$ \\
$\begin{array}{l}\text { Crumpled } \\
\text { cabinet }\end{array}$ & 4 & 185 & $3 \%$ \\
$\begin{array}{l}\text { Crushed fin } \\
\text { Scratched } \\
\text { cabinet }\end{array}$ & 1 & 185 & $2 \%$ \\
$\begin{array}{l}\text { Equivalence to } \\
\text { total failures }\end{array}$ & 1 & 185 & $1 \%$ \\
\hline \hline
\end{tabular}

The failure motor noise has been equal to $69 \%$ of the present failures on the step, what makes necessary to an analysis of this item. It is also important to analysis failures on Fig. 1, in a way to visualize how much motor noise failure has a high index of occurrence.

Applying the FMEA in a product such as the item: "Engine with noise" as one of the highest indexes of failure, it was possible to take the following conclusions.

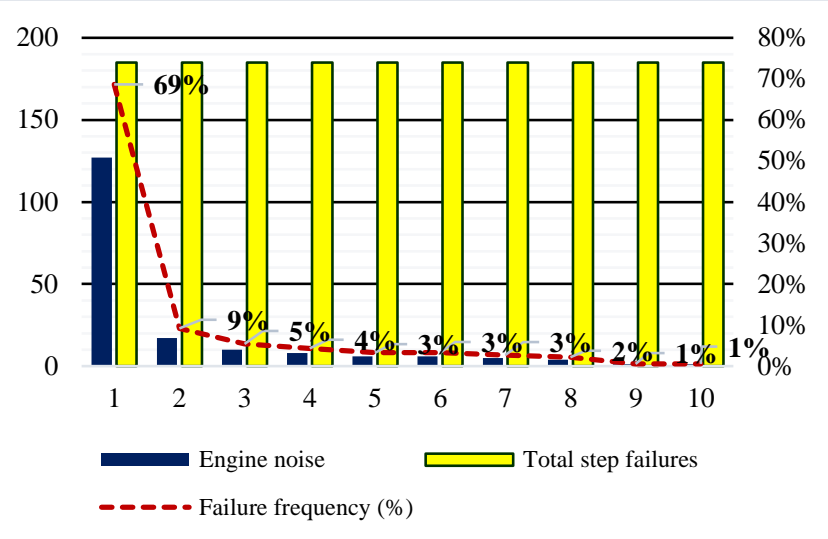

Fig. 1. Failure Final Test Graphic.

It is possible to verify in Fig. 2 that RPN reduced a lot after the application of some enhancements, almost trespassing the mark of $100 \%$ reduction. Through the actions made, it is possible to evaluate that there was a significant reduction of failures, with the FMEA application. The Table II shows this rate reduction. In other words, there is a significant reduction of failures in the FMEA application, and this shows how efficient FMEA analysis was, according to Fig. 3 and Fig. 4.

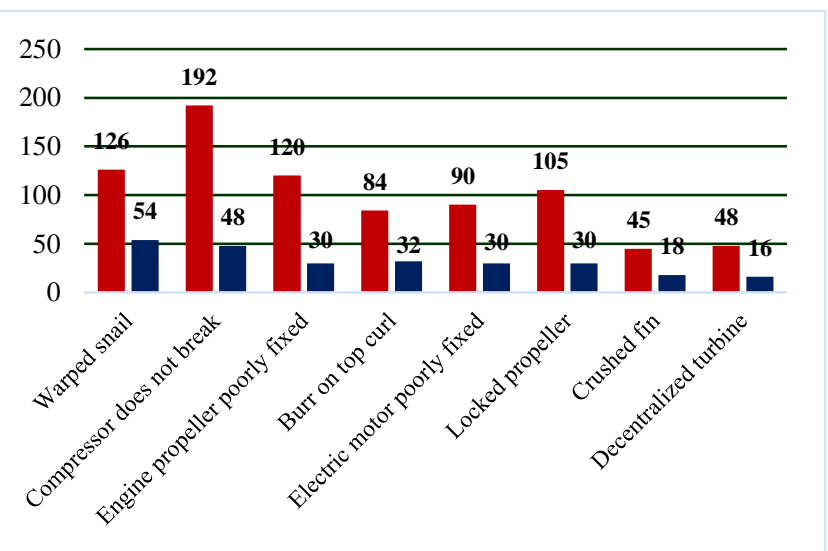

Fig. 2. Comparing to RPN after the FMEA application.

\begin{tabular}{lccc}
\multicolumn{2}{c}{ TABLE II: RPN REDUCTION PERCENTAGE POINTS } \\
\hline \multicolumn{1}{c}{ Failure } & RPN before & RPN after & $\begin{array}{c}\text { Failure } \\
\text { reduction (\%) }\end{array}$ \\
\hline $\begin{array}{l}\text { Warped snail } \\
\begin{array}{l}\text { Compressor } \\
\text { does not break }\end{array}\end{array}$ & 126 & 54 & $57 \%$ \\
$\begin{array}{l}\text { Engine } \\
\text { propeller poorly }\end{array}$ & 192 & 48 & $75 \%$ \\
$\begin{array}{l}\text { fixed } \\
\text { Burr on top curl }\end{array}$ & 84 & 30 & $75 \%$ \\
$\begin{array}{l}\text { Electric motor } \\
\text { poorly fixed }\end{array}$ & 90 & 32 & $62 \%$ \\
$\begin{array}{l}\text { Locked } \\
\text { propeller }\end{array}$ & 105 & 30 & $67 \%$ \\
$\begin{array}{l}\text { Crushed fin } \\
\text { Decentralized } \\
\text { turbine }\end{array}$ & 45 & 30 & $71 \%$ \\
\hline \hline
\end{tabular}




\section{FAILURE MODE AND EFFECT ANALISYS - FMEA}

PRODUCT/PROCESS: Engine / Final Test

\begin{tabular}{|c|c|c|c|c|c|c|c|c|c|c|c|c|c|c|c|}
\hline \multicolumn{5}{|c|}{ MODEL: QCI108BB } & \multicolumn{11}{|c|}{ Responsible: Sheyla Cardoso / William Nicolas } \\
\hline $\begin{array}{l}\text { MATERIAL } \\
\text { PROD/PROC. }\end{array}$ & FUNCTION & $\begin{array}{l}\text { FAILURE } \\
\text { MODE }\end{array}$ & $\begin{array}{l}\text { FAILURE } \\
\text { EFFECT }\end{array}$ & $\begin{array}{l}\text { FAILURE } \\
\text { CAUSE }\end{array}$ & S. & $\mathbf{0 .}$ & D. & RPN & $\begin{array}{l}\text { RECOMMENDED } \\
\text { ACTION }\end{array}$ & RESPONSIBLE & ACTIONS TAKEN & S. & $\mathbf{0}$. & D. & RPN \\
\hline \multirow{4}{*}{ Motor } & \multirow{4}{*}{$\begin{array}{l}\text { Engine } \\
\text { without noise }\end{array}$} & \multirow{4}{*}{$\begin{array}{l}\text { Engine } \\
\text { with noise }\end{array}$} & \multirow{2}{*}{ Warped snail } & $\begin{array}{c}\text { Supplier } \\
\text { process failure }\end{array}$ & \multirow{2}{*}{6} & \multirow{2}{*}{7} & \multirow{2}{*}{3} & \multirow{2}{*}{126} & $\begin{array}{l}\text { Conduct visits to the supplier } \\
\text { and request frequent reports } \\
\text { of batch inspections }\end{array}$ & IQC Quality & $\begin{array}{l}\text { Requested frequent reports of } \\
\text { batch inspections }\end{array}$ & \multirow{2}{*}{6} & \multirow{2}{*}{3} & \multirow{2}{*}{3} & \multirow{2}{*}{54} \\
\hline & & & & $\begin{array}{l}\text { Storage when } \\
\text { transporting }\end{array}$ & & & & & $\begin{array}{l}\text { Conduct training for the } \\
\text { correct transport and storage } \\
\text { of products }\end{array}$ & Logistics & $\begin{array}{l}\text { Training was carried out for the } \\
\text { correct transport and storage of } \\
\text { products }\end{array}$ & & & & \\
\hline & & & \multirow[b]{2}{*}{$\begin{array}{l}\text { Compressor } \\
\text { does not start }\end{array}$} & $\begin{array}{c}\text { Poorly } \\
\text { positioned snail }\end{array}$ & & & & & $\begin{array}{l}\text { Perform daily checklist for } \\
\text { critical parts }\end{array}$ & Production & $\begin{array}{l}\text { Weekly checklist for critical } \\
\text { parts }\end{array}$ & \multirow[b]{2}{*}{8} & \multirow[b]{2}{*}{3} & \multirow[b]{2}{*}{2} & \\
\hline & & & & $\begin{array}{l}\text { Strange item in } \\
\text { the device }\end{array}$ & 8 & 6 & 4 & 192 & $\begin{array}{l}\text { Track line for the most } \\
\text { critical models and set SPEC } \\
\text { for extraneous item } \\
\text { identification }\end{array}$ & $\begin{array}{l}\text { Process and } \\
\text { Quality } \\
\text { Engineering }\end{array}$ & $\begin{array}{l}\text { Line tracking done for the most } \\
\text { critical models and defined } \\
\text { SPEC for extraneous item } \\
\text { identification }\end{array}$ & & & & 48 \\
\hline \multirow{4}{*}{ Motor } & \multirow{4}{*}{$\begin{array}{l}\text { Engine } \\
\text { without noise }\end{array}$} & \multirow{4}{*}{$\begin{array}{l}\text { Engine } \\
\text { with noise }\end{array}$} & \multirow{3}{*}{$\begin{array}{l}\text { Engine } \\
\text { propeller } \\
\text { insecure }\end{array}$} & $\begin{array}{l}\text { Operational } \\
\text { failure }\end{array}$ & & & & & $\begin{array}{l}\text { Apply Assembly Work Guide } \\
\text { in the process for new } \\
\text { operators; } \\
\text { Update to existing ones }\end{array}$ & $\begin{array}{c}\text { Process } \\
\text { Engineering }\end{array}$ & $\begin{array}{l}\text { Applied in-process assembly } \\
\text { Work Guide for new operators; } \\
\text { Updated existing ones }\end{array}$ & \multirow{3}{*}{5} & \multirow{3}{*}{2} & \multirow{3}{*}{3} & \\
\hline & & & & $\begin{array}{c}\text { Poorly } \\
\text { positioned snail }\end{array}$ & 5 & 4 & 6 & 120 & $\begin{array}{l}\text { Conduct assembly training in } \\
\text { the process } \\
\text { Conduct assembly training in } \\
\text { the process }\end{array}$ & $\begin{array}{l}\text { Process } \\
\text { Engineering }\end{array}$ & $\begin{array}{l}\text { Assembly training carried out in } \\
\text { the process }\end{array}$ & & & & 30 \\
\hline & & & & $\begin{array}{l}\text { Turbine poorly } \\
\text { fitted }\end{array}$ & & & & & $\begin{array}{l}\text { Conduct assembly training in } \\
\text { the process } \\
\text { Conduct assembly training in } \\
\text { the process }\end{array}$ & $\begin{array}{c}\text { Process } \\
\text { Engineering }\end{array}$ & $\begin{array}{l}\text { Assembly training carried out in } \\
\text { the process }\end{array}$ & & & & \\
\hline & & & $\begin{array}{l}\text { Burr on top } \\
\text { snail }\end{array}$ & $\begin{array}{l}\text { Supplier } \\
\text { process failed }\end{array}$ & 4 & 3 & 7 & 84 & $\begin{array}{l}\text { Perform visits to the supplier } \\
\text { and request frequent reports } \\
\text { of part inspections }\end{array}$ & IQC Quality & $\begin{array}{l}\text { Requested frequent reports of } \\
\text { batch inspections }\end{array}$ & 4 & 2 & 4 & 32 \\
\hline
\end{tabular}




\section{FAILURE MODE AND EFFECT ANALISYS - FMEA}

Data: $15 / 02 / 2021$

\begin{tabular}{|c|c|c|c|c|c|c|c|c|c|c|c|c|c|c|c|}
\hline \multicolumn{16}{|c|}{ PRODUCT/PROCESS: Engine / Final Test } \\
\hline \multicolumn{5}{|c|}{ MODEL: QCI108BB } & \multicolumn{11}{|c|}{ Responsible: Sheyla Cardoso / William Nicolas } \\
\hline $\begin{array}{l}\text { MATERIAL } \\
\text { PROD/PROC. }\end{array}$ & FUNCTION & $\begin{array}{l}\text { FAILURE } \\
\text { MODE }\end{array}$ & $\begin{array}{l}\text { FAILURE } \\
\text { EFFECT }\end{array}$ & $\begin{array}{l}\text { FAILURE } \\
\text { CAUSE }\end{array}$ & S. & o. & D. & RPN & $\begin{array}{c}\text { RECOMMENDED } \\
\text { ACTION }\end{array}$ & RESPONSIBLE & ACTIONS TAKEN & S. & $\mathbf{0}$. & D. & RPN \\
\hline \multirow{4}{*}{ Motor } & \multirow{4}{*}{$\begin{array}{c}\text { Engine } \\
\text { without noise }\end{array}$} & \multirow{4}{*}{$\begin{array}{l}\text { Engine with } \\
\text { noise }\end{array}$} & \multirow{4}{*}{$\begin{array}{l}\text { Electric motor } \\
\text { poorly fixed }\end{array}$} & $\begin{array}{l}\text { Wrong } \\
\text { screw }\end{array}$ & \multirow{4}{*}{5} & \multirow{4}{*}{3} & \multirow{4}{*}{6} & \multirow{4}{*}{90} & $\begin{array}{l}\text { Apply attention to receiving } \\
\text { material from suppliers }\end{array}$ & IQC Quality & $\begin{array}{l}\text { Applied point of attention } \\
\text { when receiving material from } \\
\text { suppliers }\end{array}$ & \multirow{4}{*}{5} & \multirow{4}{*}{2} & \multirow{4}{*}{3} & \multirow{4}{*}{30} \\
\hline & & & & $\begin{array}{l}\text { Lack of } \\
\text { threading }\end{array}$ & & & & & $\begin{array}{l}\text { Request preventive } \\
\text { maintenance report of the } \\
\text { supplier's process machinery }\end{array}$ & IQC Quality & $\begin{array}{l}\text { Requested preventive } \\
\text { maintenance report of the } \\
\text { supplier's process machinery }\end{array}$ & & & & \\
\hline & & & & $\begin{array}{l}\text { Burr on the } \\
\text { thread }\end{array}$ & & & & & $\begin{array}{l}\text { Request frequent reports of } \\
\text { part inspections from the } \\
\text { supplier }\end{array}$ & Quality Supervisor & $\begin{array}{l}\text { Requested from the supplier } \\
\text { frequent reports of } \\
\text { inspections of the parts }\end{array}$ & & & & \\
\hline & & & & $\begin{array}{c}\text { Operational } \\
\text { failure }\end{array}$ & & & & & $\begin{array}{l}\text { Conduct assembly training in } \\
\text { the process }\end{array}$ & Process Engineering & $\begin{array}{l}\text { Assembly training carried out } \\
\text { in the process }\end{array}$ & & & & \\
\hline \multirow{4}{*}{ Motor } & \multirow{4}{*}{$\begin{array}{l}\text { Engine } \\
\text { without noise }\end{array}$} & \multirow{4}{*}{$\begin{array}{l}\text { Engine with } \\
\text { noise }\end{array}$} & \multirow{4}{*}{$\begin{array}{l}\text { Propeller } \\
\text { locked }\end{array}$} & $\begin{array}{l}\text { Wrong } \\
\text { screw }\end{array}$ & \multirow{4}{*}{5} & \multirow{4}{*}{3} & \multirow{4}{*}{7} & \multirow{4}{*}{105} & $\begin{array}{l}\text { Apply attention to receiving } \\
\text { material from suppliers }\end{array}$ & IQC Quality & $\begin{array}{l}\text { Applied point of attention } \\
\text { when receiving material from } \\
\text { suppliers }\end{array}$ & \multirow{4}{*}{5} & \multirow{4}{*}{2} & \multirow{4}{*}{3} & \multirow{4}{*}{30} \\
\hline & & & & $\begin{array}{l}\text { Lack of } \\
\text { threading }\end{array}$ & & & & & $\begin{array}{l}\text { Request preventive } \\
\text { maintenance report of the } \\
\text { supplier's process machinery }\end{array}$ & IQC Quality & $\begin{array}{l}\text { Requested preventive } \\
\text { maintenance report of the } \\
\text { supplier's process machinery }\end{array}$ & & & & \\
\hline & & & & $\begin{array}{l}\text { Burr on the } \\
\text { thread }\end{array}$ & & & & & $\begin{array}{l}\text { Request frequent reports of } \\
\text { part inspections from the } \\
\text { supplier }\end{array}$ & Quality Supervisor & $\begin{array}{l}\text { Requested from the supplier } \\
\text { frequent reports of } \\
\text { inspections of the parts }\end{array}$ & & & & \\
\hline & & & & $\begin{array}{c}\text { Propeller } \\
\text { poorly fitted }\end{array}$ & & & & & $\begin{array}{l}\text { Conduct assembly training in } \\
\text { the process }\end{array}$ & Process Engineering & $\begin{array}{l}\text { Assembly training carried out } \\
\text { in the process }\end{array}$ & & & & \\
\hline \multirow{4}{*}{ Motor } & \multirow{4}{*}{$\begin{array}{l}\text { Engine } \\
\text { without noise }\end{array}$} & \multirow{4}{*}{$\begin{array}{l}\text { Engine with } \\
\text { noise }\end{array}$} & & $\begin{array}{c}\text { Incorrect } \\
\text { storage }\end{array}$ & \multirow{3}{*}{3} & \multirow{3}{*}{3} & \multirow{3}{*}{5} & \multirow{3}{*}{45} & $\begin{array}{l}\text { Conduct training for fin } \\
\text { storage }\end{array}$ & Logistics & $\begin{array}{l}\text { Training carried out for fin } \\
\text { storage }\end{array}$ & & & & \\
\hline & & & Crushed fin & $\begin{array}{l}\text { Shipping } \\
\text { failure }\end{array}$ & & & & & $\begin{array}{l}\text { Checklist to verify the correct } \\
\text { storage of the transport of fins }\end{array}$ & Logistics & $\begin{array}{l}\text { Checklist carried out to } \\
\text { verify the correct storage of } \\
\text { the transport of fins }\end{array}$ & 3 & 2 & 3 & 18 \\
\hline & & & & $\begin{array}{l}\text { Operational } \\
\text { failure }\end{array}$ & & & & & $\begin{array}{l}\text { Conduct assembly training in } \\
\text { the process }\end{array}$ & Process Engineering & $\begin{array}{l}\text { Assembly training carried out } \\
\text { in the process }\end{array}$ & & & & \\
\hline & & & $\begin{array}{l}\text { Decentralized } \\
\text { turbine }\end{array}$ & $\begin{array}{l}\text { Misaligned } \\
\text { hole }\end{array}$ & 4 & 2 & 6 & 48 & $\begin{array}{l}\text { Request frequent reports of } \\
\text { part inspections and keep the } \\
\text { drawing updated with the } \\
\text { supplier }\end{array}$ & $\begin{array}{l}\text { Quality Supervisor } \\
\text { and Product } \\
\text { Engineering }\end{array}$ & $\begin{array}{l}\text { Requested frequent reports of } \\
\text { part inspections and updated } \\
\text { drawing with the supplier }\end{array}$ & 4 & 1 & 4 & 16 \\
\hline
\end{tabular}




\section{CONCLUSIONS}

The aim of this work was to propose the FMEA application for a product belongs to a white-good line industry. It had been collected data related to the item, factors that influence directly on its functioning, listed the failure modes, and pondering in the way of which defined the priority degree (RPN) of each one. Subsequently, it has been simulated as an action plan, it has been pondered again each failure and obtained a new value to Risks, thus, reduced significantly almost trespassing the $100 \%$ reduction mark of failures.

In the critical item, it has been highlighted a considerable reduction of $72 \%$, focusing on how important and efficient it. is the utilization and proposal of FMEA.

Based on the FMEA application on the critical product, with focus on the failures of the item "motor", it has been concluded that providing enhancement proposed will be highly important and will bring benefits to the process and product, once it will create a large-scale reduction to the previous failures. Leaving, this way, the FMEA application proposal as a suggestion of future studies.

\section{ACKNOWLEDGMENT}

The authors thank the Production Engineering Department (DEP) of the Federal University of Amazonas (UFAM) for their support and structure.

Special acknowledgement to the institutions and people involved to the final consolidation of this work that has been authorized through the agreement 001/2020 from the Cooperação Técnico-Científica celebrated between Fundação Universidade do Amazonas (FUA), Fundação de Apoio ao Ensino, Pesquisa, Extensão e Interiorização do IFAM (FAEPI) and the company Samsung Eletrônica da Amazônia LTDA (SEDA-M), within the project's scope of capacitation and research, which has been done by the academic unity FTUFAM.

\section{REFERENCES}

Batista, S.; Oliveira, M. A., Reis, D.; Veroneze, G.; Maciel, R. (2019). Application of FMEA for improvement in the manufacturing process of mobile phones in a factory of the Industrial Pole of Manaus. International Journal for Quality Research, 13(4), 1021-1036. https://doi.org/10.24874/IJQR13.04-18.

Braaksma, A. J. J., Klingenberg, W., \& Veldman, J. (2013). Failure mode and effect analysis in asset maintenance: A multiple case study in the process industry. International Journal of Production Research, 51(4), 1055-1071. https://doi.org/10.1080/00207543.2012.674648.

Braaksma, A. J. J., Meesters, A. J., Klingenberg, W., \& Hicks, C. (2012). A quantitative method for failure mode and effects analysis. International Journal of Production Research, 50(23), 6904-6917. https://doi.org/10.1080/00207543.2011.632386.

Daneshio, N., Stratyinski, C., and Jergová, N. (2014). Failure prevention in maintenance services and logistics. Ann. Fac. Eng. Hunedoara, 12(3), 339.

Gulati, R., and Smith, R. (2009). Maintenance and reliability best practices. Industrial Press; 3rd ed. Edition, ISBN-13: 978-0831136475, 768 p.

Jun, J. and Huibin, X. (2012). Reliability Analysis of Aircraft Equipment Based on FMECA Method. Phys. Procedia, 25, 1816-1822.

Ming, W. J., Min, H., Jun, Y., and Jun, L. X. (2015). The Study of Process Reliability of Aircraft Engine. Procedia Eng., 99, 835-839.

Moubray, J. (2000). Reliability Centered Maintenance. Industrial Press; 2nd Edition, ISBN-13: 978-0831131463, 448 p.

NP EN: 13306. (2007). Maintenance terminology. p. 37.

O'Connor, A., and Moleh, A. (2016). A general cause-based methodology for analysis of common cause and dependent failures in system risk and reliability assessments. Reliab. Eng. Syst. Saf., 145, 341-350.

Oliveira, M. A. (2017). Maintenance management system based on the organization's maturity level within maintenance. Universidade do Minho, Guimarães. Portugal.

https://repositorium.sdum.uminho.pt/handle/1822/48721.

Pham, H. (2014). Handbook of Reliability Engineering. Springer Editor, 1st Edition, ISBN-13: 978-1447139393, 663 p.

Slack, N.; Chambers, S.; Johnston, R. (2008). Operation Management. McGraw-Hill/Irwin; 10th edition, $906 \mathrm{p}$.

Stamatis, D. H. (1995). Failure mode and effect analysis: FMEA from theory to execution. ASQ Quality Press; 2nd Edition, ISBN-13: 9780873893008, $494 \mathrm{p}$.

Toledo, J. C., and Amaral, D. C. (2006). FMEA-Análise do tipo e efeito de falha. GEPEQ-Grupo Estud. e Pesqui. em Qualidade-DEP-UFSC.

Voinov, K. N., Grigor'ev, A. Y., and Grigor'ev, K. A. (2016). Compressor Reliability Improvement. Procedia Eng., 150, 448-452.

Zio, E., Fan, M., Zeng, Z., and Kang, R. (2019). Application of reliability technologies in civil aviation: Lessons learnt and perspectives. Chinese J. Aeronaut., 32(1), 143-158.

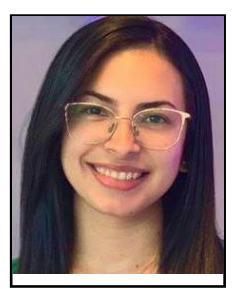

Sheyla Cardoso Andrade is a student of Production Engineering at the Federal University of Amazonas, and researcher under SUPER project.

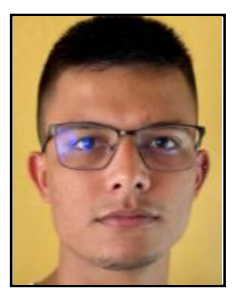

William Nicolas de Oliveira Coelho is a student of Production Engineering at the Federal University of Amazonas, and researcher under SUPER project.

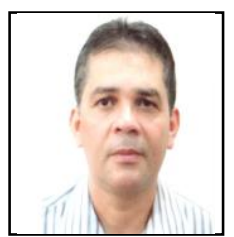

Marcelo Oliveira is an Adjunct Professor of Department of Production Engineering and member of Master Program in Production Engineering, Federal University of Amazonas. He has published several Research Papers related to Engineering area.

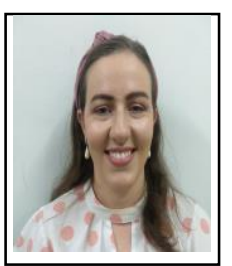

Gabriela Veroneze is an Adjunct Professor, Department of Production Engineering and member of Master Program in Production Engineering, Federal University of Amazonas. She has published several Research Papers related to Engineering area.

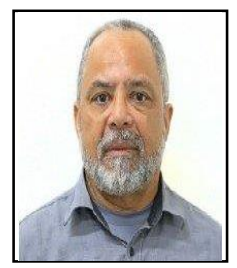

Dércio Reis is an Adjunct Professor, Department of Production Engineering and member of Master Program in Production Engineering, Federal University of Amazonas. He has published several Research Papers related to Engineering area.

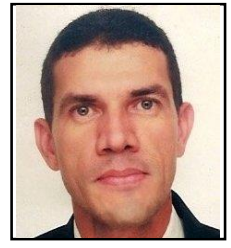

Joaquim Craveiro is an Adjunct Professor, Department of Production Engineering and member of Master Program in Production Engineering, Federal University of Amazonas. He has published several Research Papers related to Engineering area. 